\title{
A tribute to Christian Körner for his 25 years of service on the Oecologia editorial board
}

\author{
Stephan Hättenschwiler · John A. Arnone III
}

Received: 23 November 2012/ Accepted: 18 December 2012/Published online: 19 January 2013

(C) Springer-Verlag Berlin Heidelberg 2013

\section{Introduction}

At the end of 2012, Christian Körner retired as Editor-inChief of Oecologia after serving on its editorial board for 25 years. To acknowledge and honour his long and devoted service to the journal and the global research community, a number of pages of this issue of Oecologia are dedicated to Christian. The idea of this special contribution was to invite former students and postdocs of Christian and current close collaborators at the Institute of Botany of the University of Basel to report results and/or present some ideas of their current, or past, research activities in the form of original articles that underwent the same rigorous editorial assessment as any other Oecologia paper. We collected a total of 11 articles spanning from $\mathrm{CO}_{2}$ research to alpine ecology. The first paper from the "Nenzlingen project" on calcareous grassland reports on interactions among plant biodiversity, earthworms and elevated atmospheric $\mathrm{CO}_{2}$ (Arnone et al. 2013). The second paper is a synthesis of the 9-year $\mathrm{CO}_{2}$-enrichment experiment at the Stillberg treeline in Davos (Dawes et al. 2013), followed by an attempt to derive general principles in experimental plant ecology from 25 years experience in $\mathrm{CO}_{2}$ research

Communicated by Russell Monson.

S. Hättenschwiler $(\bowtie)$

Centre d'Ecologie Fonctionnelle et Evolutive (CEFE),

CNRS UMR 5175, 1919 Route de Mende,

34293 Montpellier Cedex 5, France

e-mail: stephan.hattenschwiler@cefe.cnrs.fr

\section{J. A. Arnone III}

Division of Earth and Ecosystem Sciences,

Desert Research Institute, 2215 Raggio Parkway,

Reno, NV 89512, USA
(Leuzinger and Hättenschwiler 2013). Benefiting from the former $\mathrm{CO}_{2}$ enrichment of mature canopy trees in the Swiss Canopy Crane project, Hoch et al. (2013) trace the origin of carbon for fruit production in three mast fruiting tree species. In the general context of climate warming, the following two papers report on phenological responses of a series of temperate forest trees (Vitasse et al. 2013) and an alpine herb species (Scheepens and Stöcklin 2013) along altitudinal gradients. Also in an alpine study system, Huck et al. (2013) present data on plant community shifts along erosion edges indicating the key role of certain specialist graminoid plants in the stabilisation of these erosion edges. The nitrogen $(\mathrm{N})$ cycle in pasture systems and how it is influenced by $\mathrm{N}$-fertilization and drought is the focus of the next paper (Hartmann et al. 2013), while Schädel et al.'s (2013) work contributes to a better understanding of carbon cycling in soils using a combined experimental and modelling approach. The last paper by a former co-worker of Christian is contributed by Zotz and Winkler (2013) who present a detailed assessment of the functional relevance of the velamen radicum in ephiphytic orchids for plant-water and nutrient uptake. The final contribution in this series of papers was not written by former students, postdocs or by co-workers of Christian, but connects with his scientific origins. Members of the Innsbruck group, where Christian did his $\mathrm{PhD}$, present a detailed study on frost resistance in reproductive structures and on reproductive success of alpine plant species (Wagner et al. 2013). The variety of topics covered in these papers well reflects the wide scientific interests Christian maintained during his scientific career.

In this preface to that series of papers, we not only attempt to highlight the significance of Christian's work for the journal but also his eminent and far-reaching contribution to ecological research and his strong influence on a 
next generation of scientists through his teaching and guidance (Fig. 1). Obviously, tracing the overwhelmingly diverse and rich activities of Christian is a very difficult task, and one that cannot be accomplished in these few pages. It is indeed impossible to appreciate the full breadth of Christian's work here or to draw a complete picture of the impact of his activities on both the scientific community and our society. Thus, our attempt to summarise Christian's work and its influence will inevitably remain only partial and subjective.

\section{The editorial work for Oecologia}

As former Editor-in-Chief (EIC) of Oecologia, Christian Körner helped to shape the journal and enhance its reputation as an outlet for high quality original ecological research. When he started as EIC in 1998, he had already been on Oecologia's editorial board for 10 years. During the 25 years that Christian has served on the journal's editorial board, Oecologia changed along with the methodological and theoretical advances in ecology, and with the general scientific publication habits of ever-increasing submission rates, which today is at more than 1,300 manuscripts per year across all six editorial offices of Oecologia. Indeed, in the 15 years as EIC, more than 2,800 manuscripts submitted to Oecologia passed through the editorial hands and the critical assessment of Christian. With his exceptionally broad knowledge and vision in ecology, in particular in plant physiological ecology, he screened all these submissions with the ultimate goal of helping to promote the most exciting and promising research. This task has become more challenging and timedemanding with increasing submissions. Consequently, increasing rejection rates have become inevitable as in other ecological journals with high quality and novelty standards. Despite the increasing pressure on his time, Christian Körner remained faithful to the scientific debate as one of the basic pillars of scientific work during the process of decision-making on submitted manuscripts. Together with other EICs, Christian found it necessary to implement stricter "pre-review" vetting of manuscriptsimmediately declining those that clearly did not reach the quality required to be publishable in Oecologia-in order to reduce the demand on already overloaded reviewers. However, for Christian, this "pre-review rejection" was not necessarily a firm and final decision. Acknowledging that even with his long-term experience and highly developed assessment skills, he might miss some interesting research worth publishing with a "pre-review rejection" decision, Christian was open to be challenged by the authors and to eventually send the manuscript out for review anyway. Such direct exchange between the editor and authors with a fair possibility to reconsider previous

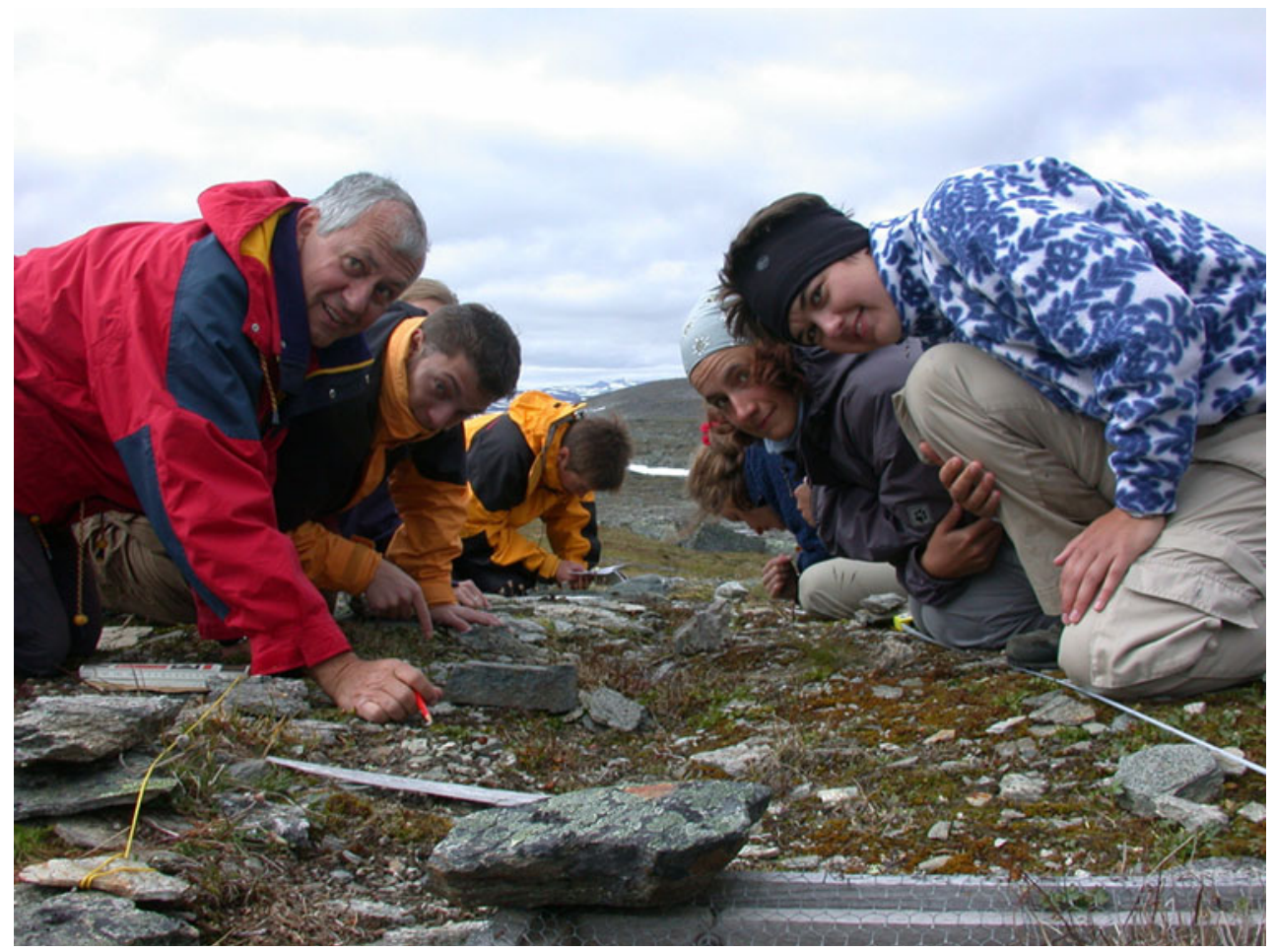

Fig. 1 Christian Körner (left) with students counting individuals of Ranunculus glacialis during a 2-week field course in Abisko, Sweden, in 2002. Photocredit: Jürg Stöcklin 
decisions on the basis of convincing scientific arguments remained dear to Christian and his editorial activity. This important part in the publication process is unfortunately disappearing more and more among the top journals for the sake of rapid turnaround. A short time lapse between submission and decision has become a key feature of competitive journals, for which, however, the scientific exchange and debate between authors and editors, which is important to Christian, should not be sacrificed.

Dealing with several hundreds of manuscripts per year involves close communication with Handling Editors (HE), referees, and authors, sometimes during several rounds of revisions. This would be completely impossible for a highly dynamic University professor without an incredibly efficient editorial office led by a skilled and highly organized assistant. Christian had the privilege to work with four wonderful editorial office assistants (Theres Paulsen 1998-2000, Annemarie Brennwald 2001-2005, Tanya Handa 2006, and Katrin Rudmann-Maurer 2007-2012). They all had the key capacity to organize their work according to the "pulsed" Oeocologia hours of Christian who travels a lot and, concordantly, was irregularly present, and this not necessarily during standard office hours. From the time I was still in Basel, I remember so well leaving the institute around midnight with the only light left in the "Oecologia office" and Christian sitting over a pile of documents. Saying good night to Christian and getting a glimpse of the strictly forbidden Oecologia office, it was impressive to see how well everything was organised, with stacks of differently coloured files indicating the status of each manuscript in the review process. The editorial assistants were admired by Christian for their awareness of manuscripts running late in the process, their patience and delicateness in the communication with impatient or, on rare occasions, even unfriendly authors and with the sometimes-slow Handling Editors. They did a wonderful job and critically facilitated Christian's work for the journal.

A quarter of a century in the service of Oecologia not only had an influence on the journal but it certainly also had an important impact on Christian in many ways. We asked him a series of questions about his relationship with Oecologia and how it evolved over the years.

"Twenty-five years seems like a long time, how did you keep your motivation to perform the duty of an editorial board member and EIC for Oecologia since 1988?"

Ch. Körner: "Strange, I never thought about whether I wanted the job. Once I accepted the task, it became a self-evident thing to attend to the piles in the editorial office. But I have to say that I could not have done this without the superb editorial assistants, who also permitted me to stay away from electronic journal managers (once these came into action) and focus on my scientific editor duties. What I do remember is that, before we re-arranged the EIC responsibility some 7 years ago, I had to deal with subjects that were far from my own field of work. Hence, I often had difficulties to appreciate the impact. With the thematic rather than continent-wise division of labor among EICs, this has greatly improved. Also, the workload was near to unbearable with only two plant EICs (one for the Americas and one for Europe and the rest of the world) before that change. At times, we had to handle $>350$ manuscripts a year, without the HE (Handling Editor) system in place. In the current system, the presence of a widely diverse set of conscientious HEs has enhanced the quality of the journal by facilitating an efficient decision process. Without that wonderful team of HEs, I could not have done the job for so long".

"You also are or have been on the editorial board of other scientific journals. What has been different or special about serving on the board of Oecologia?"

Ch. Körner: "These other journals requested mainly my time as reviewer or to contribute to discussions about journal policy and sometimes to contact potential authors for a particular type of paper. Once I succeeded Detlef Schulze as an EIC, the main issue was judging reports and filing decisions, often more difficult than writing a peer report".

"What was your moment of greatest achievement or satisfaction in your relationship with Oecologia?"

Ch. Körner: "Possibly the appearance of my first paper in Oecologia in 1982 on photosynthesis of a dominant alpine sedge, and perhaps the moment when I saw the number of ISI citations of a conceptual paper on treeline biology, that got published in Oecologia in 1998, after a near to endless and painful review process, in which I had to rebut all sorts of contrasting opinions".

"And the moment of greatest disappointment?"

Ch. Körner: "A very rare case, when an HE, who initially did a great job, suddenly disappeared from the scene without warning or excuses, not responding to mails, and simply leaving a mess of heavily delayed "undones", so I had to clear the HE's desk and write long apology letters to authors. Another unpleasant issue was a case where I had to deal with plagiarism. The case was so difficult because it was a matter of East-West contrast in scientific culture (phraseology was copied, no data were involved)". 
"Oecologia changed considerably over the past 25 years. Are you pleased with that change and proud of in its present form?"

Ch. Körner: "Did we really change? Sure, population and community ecology has now a greater share of published papers than it did in the early days, which reflects the greater appreciation of the significance of these fields. At times, it seems difficult to retain a certain thematic balance, though".

"Do you think Oecologia will still exist in 2037, and how would you like to see Oecologia evolve as a journal during the next 25 years?"

Ch. Körner: "In the tradition of the co-founder of Oecologia, Otto Lange, I would like to see more process-based plant works. We have been, and I guess still are, the strongest journal in ecological stable isotope research. I could envisage a revival of plant-water relation science, a field that many felt had its time, and now we face many ecological problems related to water that remain poorly understood. Nutrient cycle works are often quite documentary, rather than resolving the basic mechanisms that link the nutrient cycle with the carbon cycle. A field almost completely missing is the ecology of plant development (developmental ecology) including environmental influences on phenology, tissue production and organogensis. Oecologia's "concepts, review and synthesis" section is clearly not enough used and it would be good to have more scientific debate in this section. Hard to imagine that the type of ecology Oecologia represents is losing relevance or interest over the coming decades".

"Did your editorial work for Oecologia influence your own research and in what ways?"

Ch. Körner: "Yes it did. If you are forced week by week to judge scientific works by others, it is inevitable that you try to avoid the pitfalls and shortcomings in the way you ask questions, design experiments and explain results—not always with success. I guess, the young co-workers profited from that experience and with this, the group's output".

We thank Christian for sharing these reflections with the readership of Oecologia.

\section{Christian Körner's scientific activity}

The output of the Körner group is indeed impressive. Christian authored and co-authored a total of 229 indexed papers (Thomson Reuters Web of Science ${ }^{\circledR}$, mid-November
2012). These were mostly original research articles, published in a variety of different journals, ranging from specialised topical journals to general ecological journals and interdisciplinary journals. However, even though a scientist's impact is mostly judged from the number and quality of publications in peer-reviewed scientific journals, Christian also wrote regularly for the wider public. He translated the specialised scientific jargon into common language (in German or English) in journals read by a broader non-scientific public or in newspapers. His talent in explaining complex and seemingly difficult subjects attracted broad interest outside the scientific community. This was especially the case when Christian was invited by His Majesty the King of Sweden in 2003 to participate in a private royal colloquium aimed at describing and discussing the problems of global environmental change for the biosphere. Christian has excellent written and spoken communication skills that led to frequent invitations for him to lead off many plenary presentations at big international conferences. It is always extremely interesting and a great pleasure to listen to his scientific talks, where novel ideas and insights are supported by slides of the highest graphical and didactic quality. Christian's scientific assistant, Susanna Riedl, deserves a big share of the credit for creating graphics and figures for Christian's slides and figures of extraordinary quality that she often materialises from ideas and concepts that Christian sometimes just scribbles on a piece of paper during a flight or a train ride. The superb graphical quality of Christian's book Alpine Plant Life is certainly also a reason for its tremendous success, in addition, of course, to the wealth of information that Christian integrated in a synthetic and holistic way. The second edition was published in 2003 by Springer, and in 2008 the Georgian and Chinese editions were published. This year, his book Alpine Treelines was published, also by Springer, after several years of hard work to synthesise the existing knowledge on the functional ecology of global high elevation tree limits. These two books very well illustrate that functional plant ecology in the alpine environment continues to be the heart of Christian's research interest from the beginning of his scientific activity in the Austrian Alps in Walter Larcher's group in Innsbruck. Even though Christian has worked in tropical rainforests and other biomes, and has developed a world-renowned research program aimed at the investigation of how the rising atmospheric $\mathrm{CO}_{2}$ concentration is affecting plant and ecosystem functioning, he has always maintained a strong alpine research program. Since 1998, he has been the chair of the Global Mountain Biodiversity Assessment (GMBA) of DIVERSITAS, and since 2009, he has been chairing the ALPFOR (Alpine Research and Education Station, Furka) initiative with its research facility at the Furkapass, and has pursued his commitment to working jointly across the planet to strengthen our scientific understanding of alpine ecosystems. 
We cannot really give more than a very limited and general appreciation of how Christian's work influenced the international research community and the concepts and thinking in functional plant ecology. The importance of his work is perhaps best illustrated with how it is perceived by the research community. Christian's papers have been cited more than 1,000 times in the year 2011 and almost 10,000 times overall. Christian has 53 papers that have been cited at least 53 times (h-index). He was also recognized as a highly cited researcher in the area of ecology/environment by the Thomson Reuters team, a distinction that was obtained by less than one-half of one percent of all publishing researchers in ecology/environment as 1 of 21 broad subject categories in life sciences, medicine, physical sciences, engineering and social sciences.

If we had to guess the journal that Christian chose to publish most of his work, one would not be surprised to learn that Oecologia tops the list. Between 1982 and 2012, he published together with his students and co-workers a total of 35 original research articles and two review papers in Oecologia, twice as many as in the second most often used outlet for his research (Functional Ecology, published by the British Ecological Society). This number might well be even higher if he had not accepted to act as EIC on the editorial board of Oecologia. In fact, the publications he co-authored in Oecologia dropped noticeably during the last decade, reflecting Christian's scientific integrity and wish not to confound editorial responsibility with his own research activity. The citation report in the Thomson Reuters Web of Science ${ }^{\circledR}$ yields the impressive score of a total of 3,008 citations and an h-index of 29 (midNovember 2012) just for these 37 articles published in Oecologia. The Oecologia paper with the highest number of citations (374 times in mid-November 2012) is Christian's review on the re-assessment of the high elevation treeline positions and their explanations (Körner 1998), apparently a paper that was a bit of a nightmare to publish as Christian indicated to us above. In position five (cited 177 times as of mid-November 2012) is the paper he published together with his Italian colleague Franco Miglietta on the accumulation of non-structural carbohydrates in plant leaves growing around natural $\mathrm{CO}_{2}$ springs (Körner and Miglietta 1994). This latter paper is noteworthy because it well exemplifies some of the key characteristics of Christian's scientific work and approach, that we would describe as creativity, spontaneity, persistence and conviction. At a time when most colleagues around the globe working in the rapidly developing field of " $\mathrm{CO}_{2}$ research" were doing experiments with isolated plants under strongly controlled conditions, Christian was on an official institutional visit to the amazing natural $\mathrm{CO}_{2}$ springs in Tuscany. Immediately realizing the incredible potential to test some hypotheses on plant responses to elevated $\mathrm{CO}_{2}$ in a natural context, he improvised a rudimentary laboratory in his hotel room and sampled leaves from a large number of very different plant species growing around this $\mathrm{CO}_{2}$ spring and at nearby control sites. We still remember, at the time a first year PhD student, and a postdoctoral research assistant, the vibrant and enthusiastic spirit on Christian's floor at the Institute of Botany of the University of Basel when he discussed with us the results from the NSC (non-structural carbohydrates) analyses of the Italian samples, demonstrating a consistent increase in NSC in leaves of plants growing in the $\mathrm{CO}_{2}$-enriched atmosphere around the $\mathrm{CO}_{2}$ spring. His creative ideas and imagination were paired with curiosity and motivation that often resulted in forgetting about time, obstacles, fatigue and personal comfort during field or laboratory work, and are the main drivers in Christian's scientific activity. This is extremely motivating and contagious for students and co-workers sharing the same or similar traits, but difficult for those who do not. Christian's pace in getting things done, whether field work, writing, reading, travelling, organising, reviewing, or preparing a conference talk is impressive and very difficult to match. Given his above-average energy level, perhaps one of the biggest challenges for Christian's professional activity is accepting the more moderate pace of others and working in slow consortia. Clearly, all readers of Oecologia, and indeed the entire community of terrestrial plant and ecosystem ecologists, have profited in multiple significant ways by Christian's tremendous engagement in this highly relevant field of ecological research.

\section{Christian Körner's teaching}

We solicited comments from Christian's former graduate students, some of whom were also undergraduate students, and postdocs, on what each person felt the most significant way that working with Christian influenced her/his career, science, way of thinking, or development as a teacher. Some common themes and expressions of gratitude emerged from the responses. Almost all remarked that Christian's seemingly boundless energy, curiosity, and insatiable interest in functional plant ecology was infectious, highly motivational, and inspirational. Experiencing this enthusiasm, especially when in the field with Christian and being challenged with "thought" questions, were identified as formative experiences that allowed students to believe that they too could contribute significantly to ecological scientific understanding. These are some of the legacies of Christian's teaching.

Christian's role as a teacher extends back to the time in the 1970s when he was actually formally preparing in Innsbruck to become a high school (Gymnasium) instructor. It is compelling to believe that many of his effective 
pedagogical skills had their roots in this phase of his training. His incredible enthusiasm for learning and teaching, however, must be considered innate and a key part of his personality. During the c. 35 years of teaching, particularly from 1989 onwards when he was appointed as full professor at the University of Basel, Christian has offered courses in: plant ecology, functional plant ecology, field methods in plant and ecosystem ecology, alpine plant life and alpine ecology, global change biology, design of ecological experiments, and scientific writing. His field courses in plant ecology on the Furka Pass in Switzerland, and abroad on Teneriffe, the Mediterranean islands Ischia and Samos, and in Abisko in subarctic Sweden (Fig. 1) are also unforgettable experiences in any biology student's education. For many students, these excursions to a foreign biome with different vegetation types and new plant species were eye-openers for their ecological understanding. Beyond Basel, students in plant biology across all Germanspeaking universities continue to profit from Christian's teaching skills in the form of the "Strasburger", the standard German textbook in botany with more than a centurylong history and tradition (now available in its 36th edition), to which Christian has been contributing the ecology part since 2002. Christian has also given special courses abroad and to the international scientific community, all while taking the time to instruct local citizens in functional ecology walking tours through the botanical garden of the University of Basel. He has shared his teaching in the context of large-scale research planning and has impacted the organizations in which he participated and often led. These include: the Ecological Society of Germany, Austria, and Switzerland (GfÖ), the International Geosphere-Biosphere Programme (IGBP), the Global Change in Terrestrial Ecosystems program (GCTE), GMBA (see above), ALPFOR (see above), ProClim (Swiss forum for climate and global change), as a member of the German Academy of Sciences (Leopoldina), and as a fellow of the American Association for the Advancement of Science (AAAS).

Many students credit Christian with getting them to see the bigger picture while designing and conducting their own research, and analysing data, and to place their research in larger contexts. In parallel with this philosophical challenge and generally very favourable developmental outcome gained through Christian's mentoring, his former students, postdocs, and peers often cited Christian's ability to take what they would view as uninteresting, disappointing, or even boring results of manipulative or natural experiments and recognize hidden or subtle patterns, or possibly even dramatic interactions, when results from treatment combinations from different times during the experiments were considered together. This lifted many students' psyche out of the doldrums. Another trait that a number of those interviewed appreciated was the rapid progress they felt would be made when writing a paper through the stimulating exchange of edited drafts between Christian and themselves-with ideas, interpretations of results, and development of conclusions crystalising much more efficiently than if the student had been left to languish on his/her own. This, too, was viewed as very motivational.

Also mentioned a number of times was Christian's "courage to question so-called mainstream ideas", "to think and act big" with "remarkable boldness to find creative solutions", and to "foster critical thinking". Several former associates appreciated his "honesty and transparency, even when it came at the cost of diplomacy" because one at least understood his point of view and arguments, and the outcome was often that the "scientific community moves forward because he has the confidence to speak out and say what he thinks". Another colleague noted that "all the scientific discussions with him always left their traces in our further development as scientists but also in our lives in general".

With respect to Christian's impact on the development of teaching skills, students profited mainly by observing how Christian taught, even articulating that effective teaching includes constructing an effective theatrical "performance" in the classroom. As part of this, Christian's "gift for making science accessible to the student and lay person" were cited by a number of former associates, as was an almost "unmatched capability to distill the important message from a sea of information", "and his talent to use simple and illustrative examples to explain a complex process", as well as his "in-depth knowledge of so many topics in plant ecology and global change ecology".

Together with our former fellow students and postdoctoral associates and later generations of students, we feel a deep gratitude to have had the chance to assist in Christian's courses, to be taught and challenged by him, and to have had the privilege to do research together with him. These experiences marked our own teaching and scientific work which we continue, now dispersed in different laboratories across the world.

Acknowledgments Russ Monson is the initiator of this special contribution, and we thank him and his editorial office for his trust and continuous support in putting this special issue together. This collection of contributions would not have been possible without the willingness of all the contributing authors to present their most recent and exciting data. We thank Katrin Rudmann-Maurer for her help with "Oecologia statistics", and Tanya Handa, Günter Hoch, and Susanna Riedl for their comments that improved previous versions of this manuscript.

\section{References}

Arnone JA III, Zaller JG, Hofer G, Schmid B, Körner Ch (2013) Loss of plant biodiversity eliminates stimulatory effect of elevated $\mathrm{CO}_{2}$ on earthworm activity in grasslands. Oecologia 
Dawes M, Hagedorn F, Handa IT, Streit K, Ekblad A, Rixen C, Körner Ch, Hättenschwiler S (2013) An alpine treeline in a $\mathrm{CO}_{2-}$ rich world: synthesis of a nine-year free air $\mathrm{CO}_{2}$ enrichment study. Oecologia

Hartmann A, Barnard R, Marhan S, Niklaus P (2013) Effects of drought and $\mathrm{N}$-fertilization on $\mathrm{N}$ cycling in two grassland soils. Oecologia

Hoch G, Siegwolf R, Keel S, Körner Ch, Han Q (2013) Fruit production in three masting tree species does not rely on stored carbon reserves. Oecologia

Huck C, Körner Ch, Hiltbrunner E (2013) Plant species dominance shifts across erosion edge-meadow transects in the Swiss Alps. Oecologia

Körner Ch (1998) A re-assessment of high elevation treeline position and their explanation. Oecologia 115:445-459

Körner Ch, Miglietta F (1994) Long term effects of naturally elevated $\mathrm{CO}_{2}$ on mediterranean grassland and forest trees. Oecologia 99:343-351
Leuzinger S, Hättenschwiler S (2013) Beyond global change-what did we learn from 25 years of $\mathrm{CO}_{2}$ research? Oecologia

Schädel C, Luo Y, Evans D, Fei S, Schaeffer S (2013) Separating soil $\mathrm{CO}_{2}$ efflux into $\mathrm{C}$ pool specific decay rates via inverse analysis of soil incubation data. Oecologia

Scheepens JF, Stöcklin J (2013) Flowering phenology and reproductive fitness along a mountain slope: maladaptive responses to transplantation to a warmer climate in Campanula thyrsoides. Oecologia

Vitasse Y, Hoch G, Randin C, Lenz A, Kollas C, Scheepens J, Körner Ch (2013) Elevational adaptation and plasticity in seedling phenology of temperate deciduous tree species. Oecologia

Wagner J, Ladinig U, Hacker J, Neuner G (2013) How endangered is sexual reproduction of high-mountain plants by summer frosts? Frost resistance, frequency of frost events and risk assessment. Oecologia

Zotz G, Winkler U (2013) Aerial roots of epiphytic orchids: the velamen radicum and its role in water and nutrient uptake. Oecologia 